\title{
On Shoes and Committee Meetings: Some Thoughts on the Erasure of Women*
}

\author{
Pamela McCallum
}

\begin{abstract}
Pamela McCallum poursuit une démarche critique à travers différents discours qui encadrent le corps social. Dans cet essai, McCallum analyse le travail de l'artiste canadienne Gathie Falk qu'elle qualifie de dépaysant et enjoué. En contextualisant cet art qu'elle situe dans un environnement connu, l'artiste sonde et questionne les lieux féminins marginaux. McCallum souligne la similarité entre le travail de Falk et l'écriture des universitaires féministes des trente dernières années et démontre que, malgré que leur nombre se soit considérablement accru (dans le monde artistique, dans l'édition et dans le monde universitaire), les femmes continuent de se sentir effacées. Cet essai fait appel à des pressions contrastantes du souci du détail que Falk inspire, d'une part, et, d'autre part, aux entreprises collectives qui sont nécessaires à une pensée visionnaire, le tout étant susceptible de contrecarrer cet effacement des femmes dans l'institution.
\end{abstract}

On a grey spring day I entered the Vancouver Art Gallery to visit the retrospective exhibition of the Canadian artist Gathie Falk. Just past the Gallery's ornate circular staircase, the first room of exhibits contained Falk's startling ceramic works from the 1970s: exaggerated and tantalizing arrangements of deep red apples, a yellow tray filled with glistening lemons on neatly clipped grass, an amiable dog and a garden pot overflowing with camellias. But what drew my attention were the large mixedmedia wallpieces of shoes. Falk's shoes are sculpted of ceramic overlaid with a glaze that endows them with a glowing intensity. Mounted in neat arrangements whose symmetry brings a surreal order to an object usually found in more contingent circumstances - in unruly piles on a floor or in a closet - the rows of men's oxfords or side-zippered boots are extraordinary examples of Falk's ability to defamiliarize the everyday. To my mind, the most intriguing shoes were mounted in the northwest corner of the gallery, a piece whose primary colours - a set of eight blue running shoes mounted against a red background - reflected the playfulness of both Falk's style and the casual moment the sport shoes evoke. I had entered 
the room at the same time as a group of high school students; their energy and excitement was proving a challenge to the vigilance of the young woman security guard. As I watched "Blue Running Shoes" (for that was the name of the wallpiece), my gaze was drawn to something strangely out of place. There on the polished wood floor of the gallery was a shoe from Falk's artwork. Frantic explanations raced through my mind (Had Falk violated her usual fascination with symmetrical form and included an extra shoe? Had the exuberant teenagers dislodged one of the shoes from the wallpiece? What would be the reaction of the security guard?), and I stepped closer to "Blue Running Shoes" just in time to hear a young man, his voice inflected with amazement and pleasure, say to three friends, "My running shoes!" And, indeed they were, for he had taken off the shoe which was now placed underneath Falk's "Blue Running Shoes," and, while his friends laughed, he slid his foot back into the shoe which disappeared underneath his baggy cargo pants.

The event I had just witnessed, dramatic perhaps only to my eyes, enacted a highly unusual juxtaposition, that of an artwork and its material referent. Even more astonishing was the gap in time between the two: "Blue Running Shoes" was completed in 1973, and it was only the retro styling of the Converse-style canvas running shoes that meant a young man almost thirty years later would be wearing the same shoes as Falk had depicted. And yet, viewed from another perspective, the emphasis in her art on the everyday and the telling story of her career can be read as a mapping out of issues and questions that women artists, writers and critics have raised in the past thirty years. Falk was born in 1928 to a Manitoba Mennonite family. Poverty forced her to begin working in a warehouse at sixteen, but she managed to complete high school studying in night courses, and after the war she took up the conventional woman's profession of schoolteacher, an occupation she followed for the next thirteen years, before embarking on a full-time career as an artist. The strategies of Falk's art represent the ordinary objects which surround people in their day-today lives: her paintings and ceramic works take as their objects household chairs and sofas, clothing, the flowers and plants of an urban garden, fruit and kitchen table settings. And yet, her style defamiliarizes these all too conventional objects, depicting an unexpected and almost fantastical transformation of the ordinary into the extraordinary. So her paintings of the sidewalks near her Kitsilano home come before the viewer as vast abstract triangles of green and grey; only as one gazes at these geometri- 
cal shapes do they slowly resolve themselves into the marked concrete and trimmed grass so familiar to summer in the city. As viewers, the paintings and sculptures of this remarkable contemporary artist remind us to attend carefully to the details of daily life whether they be the roughened surface of the concrete on which we walk, the deep red streak near the stem of a Spartan apple, or the shaping of canvas and rubber in the running shoes we wear.

Falk's career and the strategies of her artworks uncannily mirror many of the issues which have been foregrounded in the work of feminist scholars during the past three decades. Women have not only taken up questions and problems in canonical authors, but they have also retrieved and revived the marginalized sites of women's writing: diaries, journals, lifewriting, letters and so on. Building on the well-known slogan, "the personal is political," feminist scholars have also drawn attention to the effects of a wide range of institutional practices in sustaining and reproducing modes of domination and hierarchies within universities. It is intriguing and somewhat puzzling, then, to ask why, in the context of such accomplishments, that women continue to feel invisible, to feel under erasure. Still more puzzling, an increase in visibility would seem to be born out by substantial changes in women's presence in universities. The number of women enrolled in full time studies has risen significantly from 1970 on until women now make up more than 50 percent of undergraduates. While the increase in women graduate students and faculty is less, it nevertheless represents steady growth. I want to address the problem of women's invisibility within the universities from two perspectives, one negative, one positive. Listen to these reflections, from Women of Academe: Outsiders in the Sacred Grove, by an anonymous woman scholar, a senior professor who also had the administrative experience of chairing her department:

I constantly find myself running against a set of expectations that I'm not quite meeting. The odd man out again. And I have found that to be very much the case in administration as well, in that I was very aware of the extent to which competition is at the heart of the way people interact with one another. Always sizing one another up ... I mean if you take a look at a committee that's been brought together to work on a particular task and if you look at the group of people who come together for the first time and sort of listen to what's going on, 
underneath what's being said, you hear an awful lot of sizing one another up, trying to establish position in a pecking order, and I was very, very conscious of the extent to which that was going on, especially in administration... Or take a colloquium, when you go to speak somewhere or someone comes to your department to speak, if you listen to the questions that are being asked afterward, they're not just questions, they're assertions - I know more than you do. Look at me, aren't I the knowledgeable one? (61)

The words of the speaker seem to represent nothing quite so much as a polite and restrained version of the "war of all against all," the famous phrase of the seventeenth-century philosopher, Thomas Hobbes, in his description of a projected state of nature. The great Canadian political theorist C.B. Macpherson, in his book Political Theories of Possessive Individualism, has reminded us that Hobbes' philosophy seeks to construct less a lost state of nature than the emergent conditions of capitalist society. In brief, (and I am aware here of summarizing the argument of a complex book), Macpherson suggests that Thomas Hobbes, John Locke, and later theorists such as John Stuart Mill, articulated a set of ideological assumptions constructing the individual as the possessor of capacities and abilities which he or she may then develop and sell in a market economy. Undoing the affiliations of feudal duties and responsibilities, possessive individualism is a construction which is analyzed in cultural texts, but to which we are much less alert in our daily lives. Its workings are especially insidious within the university which situates its faculty members as the possessors of their own academic careers, and which invites women to take up the positionings defined by a masculinist middle-class institutional culture, thereby blending into invisibility. If women artists like Gathie Falk have reminded us to be alert to the nuances of the everyday, we need to take this awareness into a critical self-reflection on how our daily, often apparently insignificant acts, reinforce and extend a culture which we might wish to transform. I am thinking here of all the small day-to-day interactions, the sometimes silent, but eloquent behaviour in meetings to which the anonymous speaker in Women of Academe draws our attention: the assumption that others will pick up the pieces for us, the authoritative speech patterns which command attention or their opposite, emotional excesses, the supposition that others exist to support our own projects and what is best for us is of most benefit to them - all of these strategies 
attempt to manipulate situations into the praxis of one individual. While not losing sight of the long-term goal of substantive transformation of academic institutions, we also need to be vigilant and self-reflective about the smaller day-to-day interactions which make up professional lives.

My second point is a related one, the question of coalitions and collective politics. In a 1996 interview and dialogue with seven other feminist activists and scholars published in Signs, Charlotte Bunch comments,

I do not see the feminist discourse in this country [she is speaking about the United States] addressing the practical problem of how to bring women back together so they strengthen each other. We do not need to call for a single voice or view, but we do need to ask ourselves, What are our commonalities? When is a universal concept of humanity useful? I think feminist theory does not address these issues enough because most of the theoreticians do not undertand the practical problems inherent in the theory. There needs to be more dialogue between those engaged in trying to make change in the world and those writing those theories. (933)

The ability to work collectively with others with whom one might not be in complete agreement - here theorists and activists, but the issue has general implications - is a substantive foundation for any politics which seeks to transform institutions. Feminist scholars and activists need to confront the sobering truth that those working from the right have been much more successful at forging alliances and coalitions than those working from the left (I am thinking here, for instance, of the ability of fundamentalist Protestant and Roman Catholic groups to work together in the anti-abortion movement).

Later on in the conversation, Bunch raises the question of an overall vision, what she calls "a bottom line" (945). "When we are viewed as being totally relativist ethically, we are not very compelling to people. The question is, Is there a way to express feminist values in language that is not totalizing, that is not denying diverse voices, but that actually puts forth a vision? ... We need to be less afraid of putting forward some of these visions and talking about them" (946). Because the universities have been the institutions within which theories of difference and the critiques of totalizing claims have been developed, it is perhaps understandable that scholars have been reluctant to initiate critical thinking about the implica- 
tions of so much research work and writing in recent decades. The time may be ripe, however, for such critical reflections. Nothing would counteract the erasure of women within the institution so much as strong coalitions and collectivities. The two issues I have raised here may seem to contradict one another, asking, on the one hand, for the attention to detail that Falk's art so impressively underscores and represents, and, on the other, for the expansive and visionary thinking that offers challenges to what exists. These two pressures - however different - are the tensions through which any efforts towards change must inevitably work: visions of what might be altered shape and inform self-reflective considerations of possible changes in unregarded day-to-day actions, changes which themselves might be a small step towards larger tansformations.

\section{Note}

* This essay was prepared as a discussion paper for the colloquium "Women Under Erasure," sponsored by the research group Feminism and Cultural Texts (F.A.C.T.) at the University of Calgary in March 2000.

\section{Works Cited}

Aisenberg, Nadya and Mona Harrington, eds. Women of Academe: Outsiders in the Sacred Grove. Amherst: U of Massachusetts P, 1988.

Hartmann, Heidi et al. "Bringing Together Feminist Theory and Practice: A Collective Interview." Signs 21.4 (1996): 917-51.

Macpherson, C.B. The Political Theory of Possessive Individualism: Hobbes to Locke. Oxford: Oxford UP, 1964.

Vancouver Art Gallery. Exhibit Guide to Gathie Falk: A Nationally Touring Exhibition. February 2000. 